\title{
The relationship between headache and chronic musculoskeletal complaints: an 11-year follow-up in the The Nord-Trøndelag Health Study (HUNT)
}

\author{
LJ Stovner ${ }^{1 *}$, K Hagen $^{2}$, M Linde ${ }^{2}$, TJ Steiner ${ }^{1}$, JA Z wart $^{3}$ \\ From The European Headache and Migraine Trust International Congress \\ London, UK. 20-23 September 2012
}

\section{Background and aim}

Chronic daily headache $(\mathrm{CDH})$ and chronic musculoskeletal complaints (CMSCs) are associated disorders, but whether there is a causal relationship between them is unclear.The aim of the study was to determine whether CMSCs are associated with the subsequent development of $\mathrm{CDH}$ and vice versa.

\section{Methods}

This longitudinal population-based cohort study used data from two consecutive surveys in the Nord-Trøndelag Health Study (HUNT 2 and 3) performed in 1995-1997 and 2006-2008. Amongst the 51383 participants aged $\geq 20$ years at baseline, 41766 were eligible approximately 11 years later. Of these, 26197 (63\%) completed the questions regarding headache and CMSCs in HUNT 3.

\section{Results}

A bidirectional relationship was found between headache and CMSCs. In the multivariate analyses adjusting for potential confounders, a nearly twofold risk (OR 1.8; 95\% CI 1.5-2.3) for developing CDH was found for those with CMSCs at baseline. Vice versa, a similarly elevated risk of CMSCs (OR 1.8; 95\% CI 1.2-2.6), and even higher risk of chronic widespread MSCs (OR 2.7; 95\% CI 1.6-4.7), was found at follow-up amongst those with $\mathrm{CDH}$ at baseline.

\section{Conclusion}

Chronic musculoskeletal complaints predispose to $\mathrm{CDH}$ and $\mathrm{CDH}$ predisposes to CMSCs 11 years later. This may have relevance to understanding the pathophysiology of

Department of Neuroscience, Norwegian university of Science and

Technology, UK

Full list of author information is available at the end of the article these disorders. CMSCs should be treated not only to relieve them but also to prevent the development of $\mathrm{CDH}$, and vice versa.

\section{Author details}

'Department of Neuroscience, Norwegian university of Science and Technology, UK. ${ }^{2}$ Department of Neuroscience, Norwegian university of Science and Technology, Norway. ${ }^{3}$ Oslo University Hospital, Norway.

Published: 21 February 2013

doi:10.1186/1129-2377-14-S1-P12

Cite this article as: Stovner et al:: The relationship between headache and chronic musculoskeletal complaints: an 11-year follow-up in the The Nord-Trøndelag Health Study (HUNT). The Journal of Headache and Pain 2013 14(Suppl 1):P12.

\section{SpringerOpen ${ }^{\circ}$}

(c) 2013 Stovner et al; licensee Springer. This is an Open Access article distributed under the terms of the Creative Commons Attribution License (http://creativecommons.org/licenses/by/2.0), which permits unrestricted use, distribution, and reproduction in any medium, provided the original work is properly cited.
Submit your manuscript to a SpringerOpen ${ }^{\circ}$ journal and benefit from:

- Convenient online submission

- Rigorous peer review

- Immediate publication on acceptance

- Open access: articles freely available online

- High visibility within the field

- Retaining the copyright to your article

Submit your next manuscript at $>$ springeropen.com 